\title{
Pranje novca: korelacija procjene rizika i sumnjivih transakcija
}

\section{Cindori, Sonja}

Source / Izvornik: Odabrani prijevodi, 2013, 4, 1 - 21

Journal article, Published version

Rad u časopisu, Objavljena verzija rada (izdavačev PDF)

https://doi.org/10.3326/op.16

Permanent link / Trajna poveznica: https:/urn.nsk.hr/urn:nbn:hr:242:204718

Rights / Prava: Attribution-NonCommercial-NoDerivatives 4.0 International/ImenovanjeNekomercijalno-Bez prerada 4.0 međunarodna

Download date / Datum preuzimanja: 2023-04-26

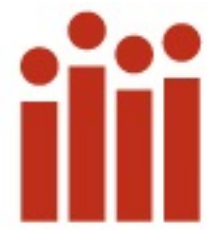

Institute of Public Finance Repository

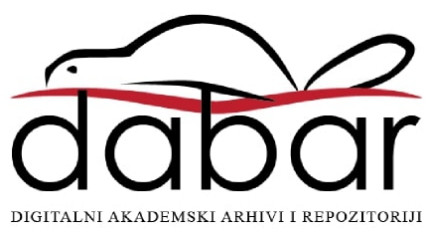


Institut za

javne financije

Smičiklasova 2I | Zagreb

www.ijf.hr | ured@ijf.hr

T: oI/4886-444 | F: OI/48I9-365

\section{OdABRANI PRIJEVODI}

ISSN I847-7445

\section{BR. 16/13}

citirati: Cindori, S., 20I3. "Money laundering: correlation between risk assessment and suspicious transactions". Financial Theory and Practice, 37 (2), I8I-206.

http://www.fintp.hr/upload/files/ftp/2013/2/cindori.pdf

Svi Odabrani prijevodi dostupni su na: http://www.ijf.hr/hr/publikacije/ca sopisi/I2/odabrani-prijevodi/III/

\section{PRANJE NOVGA: KORELAGIJA PROGJENE RIZIKA I SUMNJIVIH TRANSAKCIJA}

\author{
SONJA CINDORI \\ PREGLEDNI ČLANAK ${ }^{* *}$ \\ JEL: K42 \\ DOI: $10.3326 /$ op.16
}

\section{SAŽETAK}

Sustav procjene rizika zaživio je u Republici Hrvatskoj 2009. kao nezaobilazna posljedica uskladivanja s međunarodnim standardima, a osobito s Direktivom 2005/60/EZ o sprječavanju korištenja financijskog sustava u svrhu pranja novca i financiranja terorizma. Procjena rizika je pojam raznovrsnog sadržaja zbog čega zahtjeva, osim legislativne podloge, primjenu brojnih kriterija u svrhu učinkovite primjene u praksi. Na tom putu nalaze se sumnjive transakcije kao jedan od navedenih kriterija usko vezne uz procjenu stranke, transakcije, proizvoda ili usluge.

Nesumnjivi doprinos sumnjivih transakcija kvaliteti sustava procjene rizika potvrdit će se podvrgavanjem statističkoj analizi nekolicine zemalja zapadne $i$ sjeverne Europe. Povezivanjem striktnih, ali ujedno i dovoljno elastičnih odredbi zakona koji uređuju sustav prevencije pranja novca i financiranja terorizma sa statističkom analizom prijava sumnjivih transakcija, nametnut će se zaključci koji idu u prilog ili predstavljaju kritiku učinkovite primjene sustava procjene rizika u praksi.

Koliko su sumnjive transakcije pouzdan kriterij analize procjene rizika, odnosno može li se smatrati jedinim, pokazat će spomenuta statistička analiza, uz mogućnost donošenja zaključaka suprotnih pojedinim studijama izrađenim u međunarodnim okvirima.

Ključne riječi: pranje novca, sumnja, transakcija, rizik, procjena rizika, statistika, analiza

\footnotetext{
Autorica zahvaljuje dvojici anonimnih recenzenata na korisnim komentarima i sugestijama.

** Primljeno: 3I. siječnja 2012.

Prihvaćeno: I8. prosinca 2012.
}

Sonja CINDORI

Sveučilište u Zagrebu, Pravni fakultet, Ćirilometodska 4, Ioooo Zagreb

e-mail: scindori@pravo.hr 


\section{UVOD}

Raznovrsnost mogućih procesa pretvaranja nezakonitog novca u prividno zakoniti ukazuje na činjenicu da je pranje novca po svojoj strukturi kompleksno. Ne dovodeći u pitanje neograničenu sofisticiranost, inventivnost i maštovitost $u$ nastojanju perača da pronađu način besprijekornog pranja novca, mjere prevencije $\mathrm{u}$ tom slučaju podrazumijevaju detekciju gotovinskih i sumnjivih transakcija putem procjene rizika, odnosno provedbom "risk based approach" sustava.

Pritom se nameće pitanje provedbe ideje prevencije pranja novca putem procjene rizika, zakonitost njezina odraza u praksi i logičnost provedbe. U traženju odgovora na postavljena pitanja potrebno je prodrijeti u definiciju i prirodu procjene rizika. Na tom se putu nameću sumnjive transakcije kao okosnica svakog sustava prevencije pranja novca, čijom će se analizom utvrditi provedba procjene rizika u praksi.

\section{SMISAO "RISK BASED APPROAGH" SUSTAVA}

Sustav prevencije pranja novca koji se temelji na procjeni rizika primarno je kompleksan i nužno elastičan. S jedne su strane postavljena osnovna pravila prevencije koju provode institucije financijskog i nefinancijskog sektora, dok se $s$ druge strane traži njihov samostalni pristup u procjeni rizika $i$ posljedično tome prijavi sumnjivih transakcija.

Kao osnovno pravilo svakog sustava prevencije pranja novca i financiranja terorizma nameće se princip: svaki povećani rizik od pranja novca zahtjeva povećanu pažnju svih nadležnih institucija. Međutim, provedba tog principa nije nimalo jednostavna. Za razliku od dosad primjenjivanog sustava koji se temelji na pravilima ${ }^{2}$, sustav procjene rizika vodi se sasvim drugom logikom.

Sustav koji se temelji na pravilima inicijalno zahtjeva od svih faktora prevencije jednaku primjenu jasno i kruto postavljenih pravila u zakonom propisanim situacijama. U tom je slučaju pažnja financijskih i nefinancijskih institucija kao osnovnih faktora prevencije više usmjerena na zadovoljavanje legislativno precizno propisanih uvjeta (čime se činjenično podilazi svim uvjetima jednakim intenzitetom), nego na opipavanje bíla potencijalnim peračima novca.

Napredak $u$ poimanju značaja i obuhvata prevencije pranja novca s jednoličnog utvrđivanja zakonom zahtijevanih činjenica na sagledavanje svake pojedine stranke kroz sofisticirani filter procjene rizika zahtjeva puno veći napor. Pritom je neizbježna primjena zakonskih odredbi s jedne strane te smjernica i indikatora s druge strane koje će se prilagodbom svakom pojedinom slučaju primijeniti u praksi.

U skladu s time, sustav procjene rizika zahtjeva ne samo procjenu već i kategorizaciju rizika te njegovu konkretizaciju u obliku sumnjivih transakcija. Iako sumnjive transakcije čine njegovu okosnicu, jasno je da se ne može govoriti o nekim univerzalno prihvaćenim metodologijama koje bi opisivale prirodu i

\footnotetext{
I "Risk based approach" sustav je onaj sustav prevencije pranja novca koji se temelji na procjeni rizika, za razliku od "rule based approach" sustava koji se temelji na primjeni strogo određenih pravila.

2 "Rule based approach" sustav ili sustav koji se temelji na pravilima bio je zastupljen u prve dvije Direktive Europske unije o sprječavanju korištenja financijskog sustava u svrhu pranja novca (Direktiva 9I/308/EEC i Direktiva 200I/97/EC kojom se mijenja Direktiva 9I/308/EEC).
} 
obujam sumnjivih transakcija. One pronalaze svoje mjesto kroz identifikaciju i kategorizaciju rizika od pranja novca i financiranja terorizma što vodi uspostavi kontrolnih mehanizama koji se temelje upravo na identificiranom riziku.

Navedena tvrdnja nikako ne znači izostanak načelnih pravila koja se odnose na stranku i poslovanje stranke. Postavljena pravila predstavljaju samo okvir djelovanja, uz određeni stupanj fleksibilnosti u provedbi, sukladno procjeni rizika za svaku kategoriju stranke, transakcije, proizvoda ili pruženih usluga.

\section{I. KATEGORIZAGIJA RIZIKA}

Smjernicama FATF o pristupu temeljenom na riziku u borbi protiv pranja novca i financiranja terorizma navode se tri koraka koji vode do učinkovite provedbe sustava procjene rizika: detekcija rizika, procjena rizika te razvoj strategije upravljanja rizikom, odnosno tendencija njegovog smanjenja (Financial Action Task Force, 2007). Pritom se rizik kao osnovni pojam usko veže za stranku, proizvod ili uslugu, uključujući načine provođenja transakcije i zemljopisni položaj države koja rizik procjenjuje.

Navedena Smjernica FATF kategorizira rizik u 3 grupe: nizak rizik, visoki rizik i rizik od inovacija (novih tehnologija koje teže anonimnosti). U četvrtu grupu svrstava mehanizme razmatranja primijenjenih procedura za donošenje odluke o stupnju rizika, načinu postupanja po ustanovljenom riziku te procjeni konačnog postupanja. Procjena rizika će se prilagoditi svakom pojedincu, proizvodu i usluzi primjenom odgovarajuće mjere za ustanovljeni stupanj rizika. Pritom nije neosnovano očekivati situaciju u kojoj dvije financijske institucije, na temelju sličnih postavki, donose različite odluke.

Ovim se još jednom potvrđuje da primjena metode procjene rizika nije jednostavna. Što je veći otklon od principa procjene rizika to je veća mogućnost negativnih posljedica. $\mathrm{S}$ jedne strane precjenjivanje rizika nije moguće zbog ograničenog vremena, kadra i izvora informacija, dok je s druge strane podcjenjivanje rizika nedopustiva alternativa. Dobar sustav procjene rizika mora težiti prvenstveno ravnoteži. U tom smislu, učinkovita primjena sustava procjene rizika teži provedbi mjera dubinske analize, uključujući učinkovit nazor i razmjenu informacija između financijsko-obavještajne jedinice (u nastavku teksta: FIU) i svih institucija koje sudjeluju u prevenciji pranja novca i financiranja terorizma.

\section{SUMNJIVE TRANSAKGIJE}

Procjena rizika pranja novca po svojoj prirodi upućuje na filtriranje svih raspoloživih informacija kako bi se određene transakcije ili stranke identificirale kao sumnjive. S obzirom na kompleksnost procesa pranja novca jasno je da detekcija sumnjivih transakcija čini skup različitih mjera prevencije.

Promatrajući faze pranja novca iz perspektive provođenja sustava procjene rizika pranja novca, ipak se faze polaganja i oplemenjivanja mogu izdvojiti kao indikativne u procesu transformacije novca u neki prikladniji oblik (Cindori, 20Io). Iako se modaliteti pranja novca najčešće razlikuju ovisno o količini novca koji se želi oprati, relevantnom zakonodavstvu, gospodarstvu, financijskom tržištu, izabranom načinu djelovanja (putem financijskog ili nefinancijskog sektora) i samom procesu (fazama) kroz koji 
novac prolazi, u ove će se dvije faze najlakše procijeniti rizik pranja novca jer pružaju neograničene mogućnosti za provođenje dubinske analize stranke, proizvoda ili transakcije.

U prvoj fazi, polaganjem novca u financijski sustav ili pretvaranjem u neku drugu vrstu imovine, perači su već u prvom koraku podložni provođenju dubinske analize stranke, odnosno primjeni sustava temeljenog na procjeni rizika. U drugoj se fazi gotovina polaže na jedan ili više računa (iste ili različitih osoba) u cilju usitnjavanja većih iznosa novca, usmjeravanja na različite fizičke ili pravne osobe te $u$ cilju promjene oblika novca. Ono što će zakonodavac kasnije koristiti u okviru preventivnih mjera uočavanja sumnjivih ili nelogičnih transakcija, u fazi oplemenjivanja se najčešće koristi kao modus operandi. Polazeći od navedenog lako je zaključiti da je o detekciji sumnjivih transakcija u fazi integracije kao trećoj fazi pranja novca vrlo teško govoriti.

\section{I. SUMNJIVE TRANSAKGIJE U OKVIRIMA EUROPSKE UNIJE}

Direktive Europske unije o sprječavanju korištenja financijskog sustava u svrhu pranja novca vrlo jasno prikazuju razvojni put definicije pojma sumnjivih transakcija. Strukturiranjem osnova preventivne strategije $\mathrm{u}$ borbi protiv pranja novca, predmetne Direktive nameću potrebu za usklađivanjem i prilagođavanjem nacionalnih zakonodavstva. Pritom se ističe nužnost izgradnje sustava sprječavanja pranja novca koji se temelji na "risk based” pristupu što rezultira sve većim naglaskom na značaj i tretman sumnjivih transakcija.

Prve pokušaje postavljanja okvira preventivnog djelovanja na području sprječavanja pranja novca nalazimo u Direktivi 9I/308/EEC (u nastavku teksta: Prva direktiva). Iako vrlo elastično, njome se prvi puta određuje obuhvat pojma sumnjive transakcije. Kako kreditnim i financijski institucijama definicijom nameće obvezu provjere, s posebnom pozornošću, svake transakcije za koju se smatra da bi mogla biti povezana s pranjem novca, jasna je njezina sadržajna neodređenost i nužnost legislativne dorade na nacionalnoj razini. Uzevši u obzir da je Prva direktiva samo smjernica djelovanja na nacionalnoj razini, bez obzira što je definicija sumnjivih transakcija postavljena vrlo elastično (Graham, Bell i Elliott, 2006) ovim je pristupom na određeni način uspostavljen temelj preventivnog djelovanja.

Direktiva 200I/97/EC (u nastavku teksta: Druga direktiva) nije otišla puno dalje po pitanju razrade definicije sumnjivih transakcija, iako prepoznaje samostalne profesije i struke koje od obveze prijavljivanja sumnjivih transakcija u određenim slučajevima izuzima ${ }^{3}$.

Za razliku od prve dvije direktive, Direktiva 2005/60/EZ o sprječavanju korištenja financijskog sustava u svrhu pranja novca i financiranja terorizma (u nastavku teksta: Treća direktiva) temelji se na procjeni rizika, a samim time pitanju prepoznavanja sumnjivih transakcija pristupa na sasvim drugačiji način.

Treća direktiva pridaje sumnjivim transakcijama jednu sasvim novu ulogu postavljajući ih kao okosnicu prevencije pranja novca putem sustava procjene rizika, iako ne direktno. Pojam sumnjivih transakcija ne objašnjava $u$ formi definicije već ga "sakriva” u članku 20. pod naslovom “Obveze izvješćivanja”. Iako sadržajem djelomično ponavlja definiciju koju nalazimo još u Prvoj direktivi, pojam sumnjivih

\footnotetext{
${ }^{3}$ Vidjeti više u članku I. točka 5. Druge direktive.
} 
transakcija proširuje na složene i neobične transakcije te zasebno specificira i razrađuje percepciju pojma sumnjivosti ${ }^{4}$. Uz sve navedeno, sasvim je sigurno da se značaj sumnjivih transakcija u izgradnji sustava sprječavanja pranja novca može pronaći u obvezi svih Trećom direktivom određenih institucija i osoba na provođenje dubinske analize stranke, što potvrđuje da je stav spram sumnjivih transakcija krenuo u novom smjeru temeljenom na procjeni rizika.

Primjena mjera dubinske analize stranke i njihov sadržaj sasvim jasno ukazuju da je poimanje problematike pranja novca otišlo puno dalje od raspolaganja gotovinom, a sumnja u pranje novca aktivna je od identifikacije stranke prilikom (ili prije) uspostavljanja poslovnog odnosa do verifikacije podataka. Trag sumnjivosti proizlazi i iz ostalih sadržaja dubinske analize koji zahtijevaju stalno prikupljanje informacija o svrsi i predviđenoj prirodi poslovnog odnosa te njegovo stalno praćenje u cilju izrade profila stranke, posla i rizika te oblikovanja spoznaje o izvoru sredstava kojima stranka raspolaže.

Sličnu logiku razvoja sumnjivih transakcija možemo pratiti i u okvirima Preporuka FATF. Znakovite promjene u smjeru procjene rizika vidljive su u posljednjem revidiranom izdanju Preporuka FATF iz 20I2. Pažnja financijskog i nefinancijskog sektora sve se više usmjerava k oblastima većeg rizika, dok se, posljedično, pojednostavljuju i sve su elastičnije mjere primjenjive u području manjeg rizika 5 .

\section{SUSTAV PROGJENE RIZIKA U REPUBLIGI HRVATSKOJ}

Logikom koja slijedi tri navedene Direktive EU, razvijalo se i zakonodavstvo u Republici Hrvatskoj.

Prvi Zakon o sprječavanju pranja novca donesen je 1997. Pojam sumnjivih transakcija nije se definirao zasebno, već je proizlazio iz sadržaja identifikacije stranke ${ }^{6}$. Pritom se ne preciziraju karakteristike koje transakciju čine sumnjivom, već se sumnjivom smatra "svaka gotovinska i negotovinska transakcija za koju postoji sumnja da se radi o pranju novca”.

Izmjenama i dopunama Zakona o sprječavanju pranja novca ( ${ }^{7}$ nastavku teksta: ZSPN) učinjeni su znatni pomaci iako se, suštinski, rad Ureda za sprječavanje pranja novca (u nastavku teksta: Ured) nije previše izmijenio. Sumnjive transakcije još uvijek nisu dobile svoju definiciju, iako se kao pojam provlače kroz opće odredbe o djelovanju Ureda u “otkrivanju sumnjivih transakcija kojima se prikriva pravi izvor novca i imovine ili prava za koje postoji sumnja da su pribavljena na nezakonit način $u$ zemlji ili inozemstvu"ষ. Iako je time značaj sumnjivih transakcija neosporno istaknut, sasvim je sigurno da je rad Ureda još uvijek bio većim dijelom usmjeren na transakcije gotovog novca9 ${ }^{9}$.

\footnotetext{
${ }^{4}$ Vidjeti više u članku 22. Treće direktive.

${ }^{5}$ Revidirane preporuke su dostupne na: [http://www.fatf-gafi.org/media/fatf/documents/recommendations/pdfs/FATF\%2ORecommendations\%2O(approved\%2OFebruary\%2O2OI2)\%2Oreprint\%2OMay\%2O2OI2\%2Oweb\%2Oversion.pdf].

${ }^{6}$ Vidjeti više u čl. 4. Zakona o sprječavanju pranja novca (NN 69/97).

${ }^{7}$ Izmjene i dopune Zakona o sprječavanju pranja novca (NN II7/o3).

${ }^{8}$ Izmjene i dopune važećeg Zakona učinjene su u skladu s tada važećim međunarodnim standardima, odnosno s člankom 3. stavak 8. Druge Direktive te I3. i II. Preporukom FATF.

${ }_{9}^{9}$ Vidjeti više u godišnjim izvješćima Ministarstva financija 2005-2008. [http://www.mfin.hr/hr/godisnjaci-ministarstva] i izvješćima Moneyvala [http://www.coe.int/t/dghl/monitoring/moneyval/Evaluations/Evaluation_reports_en.asp].
} 
U duhu Treće direktive, Republika Hrvatska je novim Zakonom o sprječavanju pranja novca i financiranja terorizma ${ }^{\text {Io }}$ (u nastavku teksta: ZSPNFT) usvojila sustav procjene rizika. Drugim riječima, kroz cijelu strukturu ZSPNFT proteže se neophodnost provođenja dubinske analize stranke i procjena rizika kao krucijalna. U tom su smislu sumnjive transakcije same po sebi zauzele vodeće mjesto prilikom detekcije pranja novca i financiranja terorizma. Potvrda navedenog proizlazi i iz obveze Ureda da analitičku obradu podataka započinje upravo na osnovi obrazloženih razloga za sumnju na pranje novca ili financiranje terorizma.

Osim sumnjivih transakcija, ZSPNFT prepoznaje složene i neobične transakcije. Za razliku od sumnjivih transakcija koje su zbog samih okolnosti dosegle određeni stupanj sumnje dovoljne za utvrđivanje kaznenog djela, neobičnim se transakcijama smatraju sve one nelogične transakcije kod kojih kazneno djelo još nije utvrđeno. Uzimajući u obzir navedene kriterije nedvojbeno proizlazi da veliki broj prijavljenih sumnjivih transakcija u svojoj biti predstavlja neobične ili nelogične transakcije (Savona, 2004).

Upravo je zbog toga zakonodavac jasno ukazao na potrebu obraćanja posebne pozornosti na sve složene i neobične transakcije, kao i na svaki drugi neuobičajeni oblik transakcija koje nemaju očiglednu ekonomsku ili vidljivu pravnu svrhu ${ }^{\text {II }}$. Sustav procjene rizika svakako zahtjeva praćenje takvih transakcija, čak i u situacijama kada još nisu utvrđeni razlozi za sumnju na pranje novca ili financiranje terorizma.

\section{I. DEFINIGIJA RIZIKA I NJEGOVA PROGJENA}

6 Na osnovama procjene rizika počiva i misao vodilja ZSPNFT, što je vidljivo iz članka 7. ZSPNFT koji opisuje definiciju rizika pranja novca i financiranja terorizma. Načelno, naglasak je na riziku da će stranka zlouporabiti financijski sustav za pranje novca ili financiranje terorizma, odnosno da će neki poslovni odnos, transakcija ili proizvod biti posredno ili neposredno upotrijebljeni za pranje novca ili financiranje terorizma.

U cilju smanjenja rizika obveznik je dužan izraditi analizu rizika i pomoću nje ocijeniti rizik pojedine skupine ili vrste stranaka, poslovnog odnosa, proizvoda ili transakcije u odnosu na moguće zlouporabe vezane za pranje novca ili financiranje terorizma. Pritom, u stranke koje predstavljaju neznatan rizik može svrstati samo one stranke koje pravilnikom odredi ministar financija. Ograničenje u izradi i procjeni rizika proizlazi i iz njegove dužnosti usklađivanja sa smjernicama koje donose nadležna nadzorna tijela. Odnosno, i obveznik i nadzorno tijelo prilikom analize i procjene rizika dužni su voditi računa o specifičnosti obveznika i njegovog poslovanja, uzimajući u obzir veličinu i ustrojstvo obveznika, opseg i vrstu poslovanja, vrstu stranaka s kojima posluje i vrstu proizvoda koje nudi.

\footnotetext{
${ }^{\text {Io }}$ Zakon o sprječavanju pranja novca i financiranja terorizma (NN 87/o8).

${ }^{\text {II }}$ Vidjeti više u članku 43. ZSPNFT.
} 


\subsection{DEFINICIJA SUMNJIVIH TRANSAKCIJA}

Postupak procjene rizika neminovno veže za sobom i definiranje pojma sumnjivih transakcija. Tretirajući procjenu rizika kao misao vodilju, sumnjive transakcije ZSPNFT posljedično tretira jednakom pažnjom, nadilazeći pritom kriterije postavljene međunarodnim standardima.

U tom svijetlu ZSPNFT sumnjivom transakcijom smatra svaku pokušanu ili izvršenu gotovinsku i negotovinsku transakciju, bez obzira na njezinu vrijednost i način obavljanja. Već prvim djelom definicije sumnjive transakcije zakonodavac stavlja naglasak na aktivnu ulogu obveznika u detekciji (inovativnih) pokušaja pranja novca ili financiranja terorizma. Definicija sumnjivih transakcija u nastavku ističe tri odlike koje transakcija može (ali ne mora nužno) imati da bi se smatrala sumnjivom:

a) veza s nezakonitim izvorom ili financiranjem terorizma,

b) odstupanje od uobičajenog poslovanja stranke, uvažavajući kriterije indikatora,

c) nastojanje pronalaska rupa u zakonu.

Osim navedenih kategorizacijom utvrđenih, a mogućih razloga za sumnju na pranje novca, sumnjivom se smatra i svaka ona transakcija ili stranka za koju obveznik procijeni da postoje razlozi za sumnju na pranje novca ili financiranje terorizma ${ }^{\mathrm{I} 2}$.

Kako sumnjive transakcije po svojoj prirodi predstavljaju povećani rizik od pranja novca i financiranja terorizma, svaki ih je obveznik dužan prepoznati u okviru svoje djelatnosti, s naglaskom na specifičnost posla. Samim time se potvrđuje utemeljenost ZSPNFT na procjeni rizika, praćenju poslovanja stranke te prikupljanju informacija o svrsi i predviđenoj prirodi poslovnog odnosa. Iz tog je razloga sastavljanje liste indikatora za prepoznavanje sumnjivih transakcija i osoba u vezi s kojima postoje razlozi za sumnju na pranje novca ili financiranje terorizma zakonodavac stavio u ingerenciju obveznika ${ }^{\mathrm{I}}$.

\subsection{TRETMAN SUMNJIVIH TRANSAKGIJA}

Osim navedene definicije sumnjivih transakcija, ZSPNFT već u samom uvodu definira pojam sumnjive transakcije kao svake one transakcije za koju obveznik i/ili nadležno tijelo procijeni da u vezi s njom ili s osobom koja transakciju obavlja postoje razlozi za sumnju na pranje novca ili financiranje terorizma, odnosno da transakcija uključuje sredstva proizašla iz nezakonitih aktivnosti. Osim što je ovdje naglasak na tome da i nadležno tijelo može naknadnom strateškom analizom procijeniti i ocijeniti transakciju kao sumnjivu, evidentan je njihov značaj u sustavu prevencije pranja novca i financiranja terorizma.

Za klasifikaciju transakcija kao sumnjivih potrebno ih je prethodno podvrgnuti filteru procjene rizika, odnosno mjerama dubinske analize stranke. Dubinska analiza pritom obuhvaća utvrđivanje i provjeru identiteta stranke i njezinog stvarnog vlasnika te prikupljanje podataka o namjeni i predviđenoj prirodi poslovnog odnosa ili transakcije. Osim navedenih mjera dubinske analize, posebno je važna mjera

\footnotetext{
${ }^{12}$ Definiciju sumnjivih transakcija vidjeti u članku 42. ZSPNFT.

${ }^{13}$ Radi potpunog i cjelovitog pregleda, nadzorna tijela ipak surađuju s obveznicima prilikom izrade liste indikatora. Jednako tako i ministar financija može posebnim pravilnikom propisati obvezno uključivanje pojedinih indikatora na listu indikatora za prepoznavanje sumnjivih transakcija i osoba u vezi s kojima postoje razlozi za sumnju na pranje novca ili financiranje terorizma. Vidjeti više u članku 4I. stavak 5. i 6. ZSPNFT.
} 
kontinuiranog praćenja poslovnog odnosa. Njome se osigurava primjena sustava procjene rizika na način da analiza transakcija odgovara saznanjima obveznika o stranci, vrsti posla i rizika, uključujući prema potrebi i podatke o izvoru sredstava ${ }^{\mathrm{I} 4}$.

Po istoj se logici obavlja i nadzor nad obveznicima. Financijski inspektorat obavlja nadzor provedbe ZSPNFT kod svih obveznika isključivo na temelju procjene rizika od pranja novca i financiranja terorizma. U tom smislu, ukoliko ustanovi da pravna osoba, član uprave (ili druga odgovorna osoba u pravnoj osobi) ili fizička osoba nije izradila analizu rizika, odnosno nije odredila procjenu rizika pojedine skupine ili vrste stranaka, poslovnog odnosa, proizvoda ili transakcije, odnosno ako analizu i procjenu rizika nije uskladila sa smjernicama koje donese nadležno nadzorno tijelo, za počinjeni je prekršaj može kazniti novčanom kaznom ${ }^{15}$.

\subsection{POSTUPANJE PO SUMNJIVIM TRANSAKGIJAMA}

Tretman sumnjivih transakcija vidljiv je i po načinu na koji se sumnjive transakcije prijavljuju, kao i načinu na koji Ured po njima postupa. Ukoliko nakon izvršene analize rizika obveznik zna ili sumnja da je transakcija povezana s pranjem novca ili financiranjem terorizma, o takvoj je transakciji dužan obavijestiti Ured bez odgode ${ }^{\mathrm{I}}$, prije izvršenja transakcije. Obavijest će dostaviti telefonom, telefaksom ili na drugi prikladan način, ali je pritom dužan navesti sve razloge za sumnju na pranje novca ili financiranje terorizma te rok u kojem će transakciju izvršiti ${ }^{17}$. Posebno je važno dostavljanje obavijesti i o namjeri ili planiranju obavljanja sumnjivih transakcija neovisno o tome da li je transakcija poslije izvršena ili nije ${ }^{\mathrm{I} 8}$.

Slijedeći istu logiku, početak analitičke obrade Ured usko veže za transakcije ili osobe za koje mu obveznik ili nadležno tijelo “dostavi obrazložene razloge za sumnju na pranje novca ili financiranje terorizma”"19. Na taj je način zakonodavac stavio naglasak na postupanje Ureda po transakcijama za koje je provedena analiza rizika, a samim time ograničava bilo kakvo djelovanje temeljeno na strogom poštivanju pravila. Na taj je način ograničen broj “formalno" otvorenih predmeta koje je ZSPN dotad poticao, čime su dodatno oslobođeni resursi Ureda ${ }^{20}$.

\footnotetext{
${ }^{14}$ Preuzeto iz članka 8. ZSPNFT.

${ }^{15}$ Novčanom kaznom u iznosu od 50,00o do 700,ooo kuna kaznit će se za prekršaj pravna osoba, a iznosom od 6,000 do 30,000 kuna član uprave ili druga odgovorna osoba u pravnoj osobi. Novčanom kaznom od 35,00o do 450,ooo kuna kaznit će se za isti prekršaj fizička osoba obrtnik i fizička osoba koja obavlja drugu samostalnu djelatnost. Vidjeti više u članku 9o. ZSPNFT.

${ }^{16}$ Izuzetak prijavljivanja sumnjivih transakcija predstavlja skupina profesija i struka kao što su odvjetnici, javni bilježnici, revizori te pravne i fizičke osobe koje obavljaju računovodstvene usluge i usluge poreznog savjetovanja, glede podataka koje dobiju od stranke ili prikupe o stranci u tijeku utvrđivanja pravnog položaja stranke ili prilikom zastupanja stranke u vezi sa sudskim postupkom (što uključuje savjetovanje za predlaganje ili izbjegavanje sudskih postupaka), bez obzira na to jesu li podaci dobiveni ili prikupljeni prije, u tijeku ili nakon završenih sudskih postupaka. Vidjeti više u članku 55. ZSPNFT.

${ }^{17}$ Radi se o "aktivnoj" ulozi obveznika kao posljedici njihove inicijative, za razliku od "pasivne" dužnosti dostave podataka prema dodatnim zahtjevima Ureda (Mitsilegas, 2003).

${ }^{18}$ Ukoliko je potrebno poduzeti hitne radnje da bi se provjerili podaci o sumnjivoj transakciji ili osobi te ako Ured ocijeni da postoje razlozi za sumnju da je transakcija ili osoba povezana s pranjem novca ili financiranjem terorizma, Ured može pisanim nalogom naložiti obvezniku privremeno zaustavljanje izvršenja sumnjive transakcije najviše za 72 sata. O izdanim će nalozima Ured bez odgode obavijestiti Državno odvjetništvo RH i/ili nadležno državno odvjetništvo. Vidjeti više u članku 6o. ZSPNFT.

${ }^{19}$ Iznimno, Ured može započeti analitičku obradu sumnjivih transakcija na obrazloženi pisani prijedlog nadležnih tijela, ali samo ako bi takve aktivnosti mogle biti povezane s pranjem novca ili financiranjem terorizma. Vidjeti više u članku 64. ZSPNFT.

${ }^{20}$ Promjena legislative rezultirala je i novim strukturiranjem Ureda unutar kojeg se, između ostalih, ustrojava Odjel za prevenciju i nadzor obveznika te Odjel za strategijske analize i informacijski sustav. Vidjeti više u Uredbi o unutarnjem ustrojstvu Ministarstva financija (NN 29/o9).
} 


\subsection{KOMPLEKSNOST OBUHVATA “OBRAZLOŽENIH RAZLOGA ZA SUMNJU”}

Analitička djelatnost Ureda po "dostavljenim obrazloženim razlozima za sumnju na pranje novca ili financiranje terorizma” ide u prilog tome da Ured ne razmatra isključivo sumnjive transakcije. Predmet djelovanja Ureda bit će i sve one transakcije za koje mu obveznik dostavi obrazložene razloge za sumnju na pranje novca ili financiranje terorizma, bilo da se radi o transakcijama gotovinske naravi ili povezanim transakcijama.

Metodologije pranja novca, odnosno tipologije indikativne za fizičke osobe govore upravo o neophodnosti takvog pristupa, ali i o nužnosti fleksibilnog postupanja temeljenog na riziku. Primjerice, neuobičajeno veliki polozi gotovine kao tipologija pranja novca kod fizičkih osoba odnose se na pologe gotovine na račune svih vrsta, a odstupaju od standardnog prometa po računu stranke. Često predstavljaju znatne stavke, a nemaju pokrića u zakonitom poslovanju i dohodcima stranke. Većina transakcija ovog tipa nema logičan slijed, analizirajući gospodarske i ekonomske kriterije.

Ova metoda pranja novca već samim imenom otkriva da se radi o gotovinskim polozima, odnosno o gotovinskim transakcijama. Međutim, kako pojam "neuobičajeno" (visoki iznosi) varira od stranke do stranke, a veže se primjerice uz poslovnu pozadinu, često se radi o sumnjivim ili nelogičnim transakcijama koje po svojoj prirodi često ne dosežu zakonom postavljeni limit za "gotovinske transakcije" podložne prijavi Uredu. Kako bi se procijenio rizik takvih transakcija i utvrdio karakter sumnjivosti, na prvom je mjestu izobrazba djelatnika financijskih i nefinancijskih institucija koji će uz indikatore za prepoznavanje sumnjivih transakcija i poznavanje poslovanja stranke moći prepoznati sumnjivu transakciju i razlučiti radi li se doista o nezakonitom poslovanju.

S obzirom da neuobičajeni ili veliki polozi gotovine lako plijene pažnju službenika i otvaraju daljnje mogućnosti brze detekcije procesa pranja novca, u praksi se često koriste tzv. "povezane transakcije". Radi se o razbijanju većeg iznosa novca na nekoliko manjih iznosa (kako bi se izbjegao limit prijave gotovinskih transakcija) zbog toga što polozi manjih iznosa gotovine naizgled ostavljaju dojam izbora dobre tehnike pranja novca.

Razbijanje transakcije na manje iznose i tvorba "povezanih transakcija” u svrhu izbjegavanja limita postavljenog zakonskim odredbama, u engleskoj se literaturi naziva "structuring". Isti termin koristi i Richards uz objašnjenje pojma: "osoba izgrađuje transakciju ukoliko, djelujući samostalno ili zajedno s drugima ili u korist drugih osoba, provodi ili nastoji provesti jednu ili više transakcija u novcu, bilo kojeg iznosa, u jednoj ili više financijskih institucija, u jednom ili više dana, na bilo koji način, a u svrhu izbjegavanja zahtjeva za obavješćivanjem...” (Richards, 1998) ${ }^{2 \mathrm{I}}$. Ukoliko se na ovaj način definira termin "structuring", korisno je i indikatorima sumnjivih transakcija pridonijeti lakšem prepoznavanju povezanih transakcija koje su same po sebi elastično definirane zbog kompleksne prirode provođenja i nemogućnosti strogog ograničenja zakonskim normama.

\footnotetext{
${ }^{21}$ Slična razmišljanja postoje u Republici Hrvatskoj puno prije zakonske regulative koja propisuje preventivne mjere pranja novca. O povezanim transakcijama govori još i993. Heršak u smislu "velike financijske operacije koja se razbija u niz malih operacija s malim količinama novca” (Heršak, 1993).
} 
Prema navedenom, jasno je da i povezane transakcije, uz gotovinske i sumnjive, mogu predstavljati predmet razmatranja Ureda, ukoliko se potkrijepe "obrazloženim razlozima za sumnju na pranje novca ili financiranje terorizma”. U tom će se obliku smatrati sumnjivim transakcijama i na propisani način evidentirati u statistikama Ureda. Zbog čega je to važno i što nam statistika prijavljenih sumnjivih transakcija govori o sustavu temeljenom na procjeni rizika, utvrdit će se konkretnom analizom sumnjivih transakcija.

\section{ANALIZA SUMNJIVIH TRANSAKGIJA KAO ANALIZA SUSTAVA PROGJENE RIZIKA}

Provedba sustava temeljenog na procjeni rizika nije nimalo jednostavna, promatrajući iz kuta legislativnog određenja ili iz kuta učinkovite provedbe u praksi. Njegova je složenost posljedično vezana za sumnjive transakcije čiji je sadržaj sam po sebi neodrediv, a strogo ograničenje obuhvata nedopustivo. Upravo se na takvom legislativnom opredjeljenju temelji sustav procjene rizika.

Kako bi se dokazala učinkovitost provedbe tog istog sustava u Republici Hrvatskoj, usporedit će se statistički podaci o prijavljenim sumnjivim transakcijama u vremenu 2005-20Io. u deset različitih zemalja neovisno o njihovoj razvijenosti, veličini i usklađivanju s međunarodnim standardima.

\section{I. UTJEGAJ PRISTUPA TEMELJENOG NA RIZIKU NA BROJ PRIJAVLJENIH SUMNJIVIH TRANSAKCIJA}

Završna studija o provedbi Treće direktive Europske unije o sprječavanju korištenja financijskog sustava u svrhu pranja novca ( $\mathrm{u}$ nastavku teksta: Završna studija) ${ }^{22}$ navodi da sustav temeljen na procjeni rizika ima pozitivan utjecaj na izvješćivanje o sumnjivim transakcijama gledajući s aspekta broja prijavljenih sumnjivih ili neobičnih transakcija, kvalitete tih prijava te učinaka na detekciju sumnjivih transakcija.

Raspravom o kriteriju broja prijavljenih sumnjivih transakcija i odnosa prema kriteriju njihove kvalitete, u navedenoj je Završnoj studiji istaknuto kako su oba kriterija u međusobnoj zavisnosti. Odnosno, ustanovljeno je povećanje broja sumnjivih transakcija kao posljedica primjene sustava procjene rizika (za razliku od dotadašnjeg sustava koji počiva na pravilima), a s time u vezi i povećanje njihove kvalitete.

Kako je u Republici Hrvatskoj primjena sustava procjene rizika ukazala na upravo suprotan trend, odnosno pad broja prijavljenih transakcija, vrijedno je ovom problemu posvetiti posebnu pažnju kako bi se utvrdio stvarni odnos između broja prijavljenih sumnjivih transakcija i ostvarenja osnovnih ciljeva sustava procjene rizika.

\footnotetext{
${ }^{22}$ Dostupno na: [http://ec.europa.eu/internal_market/company/docs/financial-crime/2OIIoI24_study_amld_en.pdf].
} 
TABLICA I.

Prijave sumnjivih transakcija koje se odnose na pranje novca u periodu 2005-2010.

\begin{tabular}{|c|c|c|c|c|c|c|}
\hline Država & 2005. & 2006. & 2007. & 2008. & 2009. & 2010. \\
\hline Bugarska & 680 & 374 & $43 \mathrm{I}$ & $59 \mathrm{I}$ & 883 & $\mathrm{I}, 460$ \\
\hline Francuska & II,553 & $\mathrm{I} 2, \mathrm{O} 47$ & $\mathrm{I} 2,48 \mathrm{I}$ & I4,565 & $\mathrm{I} 7,3 \mathrm{IO}$ & 19,208 \\
\hline Hrvatska & 2,908 & $2,89 \mathrm{I}$ & 2,857 & 2,323 & 629 & 602 \\
\hline Lihtenštajn & 192 & $\mathrm{I} 6 \mathrm{I}$ & 205 & $157^{*}$ & 235 & $26 I^{*}$ \\
\hline Njemačka & $8,24 \mathrm{I}$ & 10,051 & 9,080 & 7,349 & 9,046 & II,O42 \\
\hline Rumunjska & 3,858 & 3,I95 & 2,574 & 2,332 & 2,259 & 2,925 \\
\hline Slovenija & II6 & 165 & 192 & 248 & 199 & 233 \\
\hline Srbija & 138 & 622 & I,432 & 2,884 & 3,957 & 4,537 \\
\hline Švicarska & 729 & 619 & 795 & 851 & 896 & I,I59 \\
\hline Ukrajina & 350,507 & 313,074 & 322,966 & 290,418 & 227,192 & $96,22 I^{* *}$ \\
\hline
\end{tabular}

* Prijave sumnjivih transakcija evidentirane do I. IO. 2008/20IO.

** Prijave sumnjivih transakcija evidentirane do I. 8. 2010.

Izvor: Izvješća MONEYVAL ${ }^{23}$ i godišnja izvješća navedenih država.

\section{I.I. SMANJENJE BROJA PRIJAVLJENIH SUMNJIVIH TRANSAKCIJA}

U nastojanju spoznaje prave prirode sustava procjene rizika i stvaranja veze s evidencijom broja prijavljenih sumnjivih transakcija, u nastavku će se analizirati pad broja sumnjivih transakcija evidentiranih u Republici Hrvatskoj, Sloveniji, Rumunjskoj i Ukrajini.

\section{I.I.I. REPUBLIKA HRVATSKA}

Uvidom u sumnjive transakcije vezane uz pranje novca koje su Uredu prijavljene u vremenu 20052008. jasno je vidljiva njihova konstanta. Stupanjem na snagu ZSPNFT (2009) koji sustav detektiranja i prijavljivanja sumnjivih transakcija temelji na procjeni rizika, broj prijavljenih sumnjivih transakcija smanjio se i do 5 puta (u 2009. i 20I0). Uspoređujući četiri godine u kojima se primjenjivao ZSPN (20052008) i dvije godine provođenja ZSPNFT (2009-20I0), jasno je vidljivo da je u dvije godine prijavljivanja sumnjivih transakcija prema sustavu procjene rizika prijavljeno (u prosjeku) upola manje sumnjivih transakcija nego u jednoj godini prijavljivanja u sustavu temeljenom na pravilima.

Ustanovljeni pad u broju prijavljenih sumnjivih transakcija posljedica je primjene ZSPNFT koji vrlo detaljno opisuje narav sumnjive transakcije. Osim ZSPNFT, sumnjive transakcije su tretirane i Pravilnikom o obavješćivanju Ureda za sprječavanje pranja novca o sumnjivim transakcijama i osobama $^{24}$ gdje su detaljno navedeni način i rokovi, dodatni podaci o sumnjivim transakcijama povodom obavješćivanja Ureda te elektronička dostava podataka.

Kao rezultat detaljno propisanog sadržaja sumnjive transakcije i nametanja aktivne uloge obveznicima ${ }^{25}$ prilikom izrade indikatora za prepoznavanje sumnjivih transakcija te njihovog učestalog

\footnotetext{
${ }^{23}$ Dostupno na: [http://www.coe.int/t/dghl/monitoring/moneyval/Evaluations/Evaluation_reports_en.asp].

${ }^{24}$ Pravilnik o obavješćivanju Ureda za sprječavanje pranja novca o sumnjivim transakcijama i osobama (NN I/og).

${ }^{25}$ Obveznici provedbe mjera, radnji i postupaka za sprječavanje i otkrivanje pranja novca i financiranja terorizma određeni su člankom 4. ZSPNFT.
} 
sudjelovanja u izobrazbi (provedenoj tijekom 2009. i 20IO), ${ }^{26}$ statistika samo potvrđuje porast kvalitete prijavljenih sumnjivih transakcije na uštrb kvantitete. Na taj je način potvrđena i zrelost obveznika prilikom procjene rizika i detekcije sumnjivih te neobičnih ili nelogičnih transakcija. Ova se tvrdnja većim djelom odnosi na financijski sektor, odnosno banke, zbog toga što je u vremenu 2005-2008. udio banaka u ukupnom broju prijavljenih sumnjivih transakcija 90\%, dok je u vremenu 2009-20Io. taj broj smanjen na 50\%. Unatoč tome, broj prijava sumnjivih transakcija nebankarskog i nefinancijskog sektora nije se promijenio što ostavlja prostora za usavršavanje i razvoj cjelokupnog sustava.

Razvoj sustava procjene rizika u odnosu na broj otvorenih predmeta i proslijeđenih OST očekuje se i obzirom na činjenicu da je u vremenu 2009-20Io. na temelju prijavljenih sumnjivih transakcija otvoreno 642 predmeta i odaslano 235 obavijesti o sumnjivim transakcijama $\left(\right.$ OST $\left.^{27}\right)$ nadležnim tijelima na daljnje postupanje. Odnosno, od I,23I prijavljene sumnjive transakcije od strane obveznika $u$ razdoblju 2009-20Io. Ured je otvorio 642 predmeta što iznosi 52\% prijavljenih sumnjivih transakcija u istom razdoblju, a 235 proslijeđenih OST čini ı9\% od istog broja prijavljenih sumnjivih transakcija.

\section{I.I.2. SLOVENIJA, RUMUNJSKA I UKRAJINA}

Slovenija je također zabilježila pad prijava sumnjivih transakcija u 2009, međutim potrebno je istaknuti neke specifičnosti koje su svojstvene slovenskoj tradiciji prevencije pranja novca (i financiranja terorizma). Slovenski Zakon o sprječavanju pranja novca i financiranja terorizma ${ }^{28}$ stupio je na snagu sredinom 2007. Uspoređujući broj prijavljenih sumnjivih transakcija 2005. (II6) i 2006. (I65) kad je primjenjivan sustav temeljen na pravilima, bilježi se njihov porast. Već 2007. kad je sredinom godine zakonodavstvo usklađeno s međunarodnim standardima, čime se počeo primjenjivati sustav procjene rizika, bilježi se vrlo mali porast prijavljenih sumnjivih transakcija (192) što se može objasniti primjenom novog principa djelovanja. Međutim, 2008. taj se broj povećao (248) da bi se 2009. (199) ponovno smanjio. Istim ritmom bilježi se ponovni porast prijavljenih sumnjivih transakcija u 2010. (233). Iako se radi o vrlo malim pomacima u jednako tako malom broju prijavljenih sumnjivih transakcija teško je govoriti o zakonitostima koje su usko vezane za provedbu sustava procjene rizika. Jedina konstanta je aktivno sudjelovanje financijskog sektora, poglavito banaka, od 75 do $80 \% \mathrm{u}$ ukupnom broju prijavljenih sumnjivih transakcijama u razdoblju 2008-2010 ${ }^{29}$. Usprkos tome, o određenom stupnju osviještenosti slovenskih obveznika, ali i djelotvornosti slovenskog Ureda svjedoči podatak da je ukupan broj prijavljenih sumnjivih transakcija jednak broju otvorenih predmeta.

Kao i većina zemalja, Rumunjska je tek 2008. uskladila svoje zakonodavstvo s međunarodnim standardima, iako je već 2002. prepoznala značaj prevencije financiranja terorizma. Sudeći po statističkim podacima, u razdoblju 2005-2009. vidljiv je trend smanjenja broja prijavljenih sumnjivih transakcija, osim u 20Io. kada taj broj raste. Iako broj sumnjivih transakcija raste (2,925 u 20Io),

\footnotetext{
${ }^{26}$ Godišnja izvješća Ministarstva financija za 2009. i 20Io. Dostupno na: [http://www.mfin.hr/hr/godisnjaci-ministarstva].

${ }^{27}$ Obavijest o sumnji na pranje novca ili financiranje terorizma u zemlji ili inozemstvu koju Ured dostavlja nadležnim državnim tijelima ili stranoj FIU na daljnje postupanje.

${ }_{28}$ Zakon o preprečevanju pranja denarja in financiranja terorizma, Ur. l. RS, št. 6o/2007. Dostupno na: [http://www.uppd.gov.si/si/zakonodaja_in_dokumenti/zppdft_in_podzakonski_akti/].

${ }^{29}$ Poročilo o delu Urada Republike Slovenije za preprečevanje pranja denarja za leto 20Io. Dostupno na: [http://www.uppd.gov.si/si/delovna_podrocja/podatki_o_delu_urada/].
} 
kreditne i financijske institucije i nadalje svojim prijavama sudjeluju u visokom postotku spram ukupnog broja prijavljenih sumnjivih transakcija (u 90\% slučajeva). Zaključno, u 20Io. broj prijavljenih sumnjivih transakcija povećao se $29 \%$ spram 2009. što je rezultat izobrazbe u okviru Twinning projekta u suradnji s FIU Poljske ${ }^{30}$ i primjene parametara on-line izvješćivanja (Cindori, 20o8). Povećanje broja sumnjivih transakcija podizanjem stupnja svijesti financijskog sektora (prvenstveno izobrazbom) svakako predstavlja pozitivan trend, međutim isticanje on-line izvješćivanja kao parametra (umjetnog) povećanja njihovog broja indicira negativnu okolnost.

Uz Republiku Hrvatsku, Sloveniju i Rumunjsku, Ukrajina se također nalazi na popisu država kod kojih je uočena tendencija smanjenja prijava sumnjivih transakcija. Ukrajina je specifična po svom sustavu prevencije pranja novca i financiranja terorizma utoliko što do 2003. nije imala odgovarajuću legislativu na nacionalnoj razini već se vodila isključivo međunarodnim standardima, prvenstveno Preporukama FATF. Iz tog je razloga 2002. i 2003. svrstana na "crnu listu" nekooperativnih država (Cindori, 20IO). Stupanjem na snagu Zakona o prevenciji i protudjelovanju ozakonjenja (pranja) nezakonitih sredstava proizašlih iz kaznenih djela (2003) uspostavila je sustav prevencije pranja novca, dok je usklađivanje s Trećom direktivom postigla Zakonom o prevenciji i protudjelovanju ozakonjenja (pranja) nezakonitih sredstava proizašlih iz kaznenih djela i financiranja terorizma $\left(2010^{3 \mathrm{I}}\right)$.

Bez obzira na veličinu Ukrajine, statistički podaci o prijavljenim sumnjivim transakcijama ukazuju na njihovu enormnost. Od 2005. (350,000) do 20IO. (96,22I) možemo govoriti o tendenciji pada prijavljenih sumnjivih transakcija, iako se još uvijek radi o velikim iznosima. Čak je i najmanji zabilježeni iznos od 96,22I sumnjive transakcije prijavljene u 2010. (podatak je do I. 8. 2010) I6o puta veći od broja prijavljenih sumnjivih transakcija za istu godinu npr. u Republici Hrvatskoj (6o2). Uvidom u statističke podatke iz tabele $\mathrm{I}$. i usporedbom s podacima o prijavljenim sumnjivim transakcijama u Ukrajini, $\mathrm{u}$ budućnosti se može očekivati realno smanjenje broja prijavljenih sumnjivih transakcija kao rezultat usklađenja s međunarodnim standardima i primjene sustava procjene rizika.

\section{I.2. POVEĆANJE BROJA PRIJAVLJENIH SUMNJIVIH TRANSAKCIJA}

Za razliku od trenda opadanja broja prijavljenih sumnjivih transakcija u Republici Hrvatskoj, Sloveniji, Rumunjskoj i Ukrajini, Završna studija zagovara suprotan stav. Prema Završnoj studiji, povećanje njihovog broja može se dovesti u vezu s cjelovitom primjenom sustava procjene rizika. Da li je to doista tako i u kojoj mjeri povećanje broja sumnjivih transakcija uopće može predstavljati temelj ocjene sustava procjene rizika, odgovorit će statistika nekolicine razvijenih zemalja zapadne i sjeverne Europe.

\footnotetext{
${ }^{30}$ Main elements related to National Office for Prevention and Control of Money Laundering's activity, performed within the year 20Io, Synthesis of the activity report. Dostupno na: [http://www.onpcsb.ro./ pdf/NOPCML\%2OReport\%2O2OIO.pdf].

${ }^{31}$ Law of Ukraine on Prevention and Counteraction to Legalization (Laundering) of the Proceeds from Crime or Terrorist Financing as of May I8, 2010 No. 2258 (enters into force of August 2I, 2OIO). Dostupno na: [http://www.coe.int/t/dghl/monitoring/moneyval/Evaluations/progress\%2oreports/MONEYVAL(2OIO)I_ProgRep_UKR_en.pdf].
} 


\section{I.2.I. ŠVICARSKA, FRANCUSKA, NIZOZEMSKA I NJEMAČKA}

Švicarska je zemlja koja bilježi lagani porast prijavljenih sumnjivih transakcija u vremenu 2006-2009. U 20IO. je taj porast značajniji (29\%). U Godišnjem izvješću za 20IO. ${ }^{32}$ porast broja sumnjivih transakcija opravdava se radom na dva složena slučaja iz bankarskog sektora koji su rezultirali velikim brojem obavijesti o sumnjivim transakcijama (I44). Usprkos tome, bankarski sektor i nadalje sudjeluje sa 7I\% u ukupnom broju prijavljenih sumnjivih transakcija, iako je uočen rast prijava sumnjivih transakcija $u$ sektoru usluga plaćanja, od strane fiducijara (povjerenika) i od osoba koje upravljaju imovinom.

Međutim, ono što doista ukazuje na razvijeni sustav procjene rizika odnosi se na broj prijavljenih transakcija na osnovi vlastite procjene, a ne sukladno strogim odredbama zakona. Takve su prijave indikativne za financijski sektor (banke i sektor usluga plaćanja), a iznose jednu šestinu ukupno prijavljenih sumnjivih transakcija u posljednjih osam godina. Ukupan broj prijava transakcija na osnovi vlastite procjene u promatranom razdoblju 2005-20IO. raste, zahvaljujući promjeni zakonodavstva koje dopušta njihovo dostavljanje direktno u MROS (švicarski FIU), a ne tijelima kaznenog progona.

Na osnovi navedenog možemo zaključiti da švicarski sustav prevencije pranja novca i financiranja terorizma potiče razvoj svijesti nebankarskog i nefinancijskog sektora što je vidljivo povećanjem broja prijavljenih sumnjivih transakcija upravo iz tih sektora, ali je isto tako zapaženo povećanje broja sumnjivih transakcija prijavljenih na osnovi vlastite procjene.

Nadalje, spomenuto institucionalno opredjeljenje potiče još i pitanje dostave informacija o pokušajima pranja novca, odnosno o sredstvima vezanim uz zločinačke organizacije te sredstvima proizašlim iz teških kaznenih djela ili raspolaganjem zločinačkih organizacija. Radi se o situacijama kada transakcija još nije izvršena, odnosno poslovni odnos još nije uspostavljen ${ }^{33}$. U tom je slučaju teško dokazati predikatno djelo, odnosno započeti kazneni postupak. Međutim, švicarski Federalni zakon o borbi protiv pranja novca $u$ financijskom sektoru prvenstveno je akt prevencije, čija je uloga ispunjena samim činom zaustavljanja potencijalnih perača novca u provođenju konkretne transakcije. Iako obavijesti o neizvršenim transakcijama nisu poslane u MROS, perači novca ipak nisu uspjeli plasirati sredstva putem financijskog sektora, čime im je znatno sužen krug djelovanja.

Francuska predstavlja još jedan pozitivan primjer provedbe sustava temeljenog na procjeni rizika. Statistički pregled prijavljenih sumnjivih transakcija u vremenu 2005-20Io. ukazuje na stalni rast prijava. Ono što francuski sustav čini jedinstvenim i izrazito učinkovitim odnosi se na opadanje udjela banaka u ukupnom broju prijavljenih sumnjivih transakcija (iako taj broj iz godine u godinu raste) $u$ kojem 20Io. sudjeluju s manje od 75\%. Izraziti rast prijava sumnjivih transakcija zabilježen je kod ovlaštenih mjenjača zbog povećanja trgovine zlatom i plemenitim metalima što se smatra sigurnim ulaganjem u vrijeme ekonomske i financijske krize. Osim navedenog objašnjenja postoji i mogućnost

\footnotetext{
${ }^{32}$ Annual report by the money laundering reporting Office Switzerland MROS, A publication by the Federal Office of Police, Bern. Dostupno na: [http://www.fedpol.admin.ch/content/fedpol/en/home/dokumentation/berichte/geldwaescherei.html].

${ }_{33}$ Članak 305. i 26o. Federalnog zakona o borbi protiv pranja novca u financijskom sektoru (The Federal Act on Combating Money Laundering in the Financial Sector).
} 
da povećanje ovih vrsta transakcija proizlazi iz inovativnih načina djelovanja perača novca kako bi izbjegli sofisticiranim metodama oboružani bankarski sektor.

Također, porast broja prijavljenih sumnjivih transakcija evidentan je i kod investicijskih tvrtki, savjetnika za financijska ulaganja, brokera i društava za upravljanje portfeljima. Ono što posebno svjedoči oživotvorenju provedbe sustava procjene rizika u Francuskoj prožima se kroz statističke podatke nefinancijskih institucija, posebno javnih bilježnika, voditelja dražbi, casina, revizora te ovlaštenih računovođa ${ }^{34}$ kod kojih je rast prijava sumnjivih transakcija značajan. Ovakva statistička analiza govori $\mathrm{u}$ prilog tome da su perači novca doista prionuli novim, inovativnim načinima ozakonjenja nezakonito stečenih sredstava, samo što francuski primjer ukazuje na visoku osviještenost i spremnost na detekciju sumnjivih i nelogičnih transakcija u svim sektorima provedbe prevencije pranja novca i financiranja terorizma.

U pozitivnom smjeru ide i statistička analiza nizozemskog sustava prevencije pranja novca i financiranja terorizma. Nizozemska je država koja statistički prikaz sumnjivih transakcija u sustavu prevencije pranja novca i financiranja terorizma gradi na dvije razine: razini novčanih i nenovčanih sumnjivih transakcija. Iako je u Završnoj studiji navedena kao zemlja koja bilježi pad prijava sumnjivih transakcija, taj se pad odnosi samo na novčane transfere (u 2009. je zabilježeno 32,IOo, dok je u 2010. zabilježeno 29,795).

S druge strane, statističkom je analizom utvrđen porast broja sumnjivih transakcija, ali u odnosu na nenovčane transfere ( $u$ 2009. je zabilježeno 3,453, dok je u 20Io. zabilježeno 4,408). U pogledu prijava sumnjivih transakcija koje sadržavaju nenovčane transfere, udio banaka se u 20Io. u odnosu na 2009. povećao za 28\% u ukupnom iznosu, kao i broj prijava sumnjivih transakcija casina i kartičnih kuća (iako se njihov relativni udio u ukupnom iznosu ne mijenja). $\mathrm{S}$ druge strane, prijave sumnjivih transakcija $u$ odnosu na nenovčane transfere imaju silaznu putanju posebno kod slobodnih profesija (-I4\%), trgovaca visokovrijednom robom (-43\%) te kod društava koje pružaju usluge prijenosa novca (-19\%), što predstavlja negativni trend i ne ide u prilog primjeni sustava procjene rizika. Uzevši pritom u obzir još i činjenicu da udio banaka u ukupnom broju prijavljenih sumnjivih novčanih transakcija pada, nameće se zaključak da perači novca prilikom ozakonjenja nezakonito stečenih prihoda sve više koriste nove tehnologije dostupne u okvirima financijskog sektora, odnosno novac transferiraju u svim oblicima koje dopušta moderna tehnologija.

Statistička analiza podataka o prijavljenim sumnjivim transakcijama u Njemačkoj prati isti trend rasta. U razdoblju 2008-20Io. broj prijavljenih sumnjivih transakcija raste, međutim rast se ne očituje samo u financijskom sektoru, veći i u broju prijava društva za osiguranje, poreznih savjetnika, casina, a posebno osoba koje sudjeluju u robnoj razmjeni. Uspoređujući s podatcima o prijavljenim sumnjivim transakcijama iz tabele I, Njemačka pokazuje zavidnu razinu svijesti svih institucija involviranih u provođenje sustava prevencije pranja novca i financiranja terorizma, ističući one u nefinancijskom sektoru.

\footnotetext{
${ }^{34}$ Preuzeto iz Traitement du renseignement et action contre les circuits financiers clandestins (TRACFIN), Rapport d’activité 20Io, Montreuil-sous-Bois cedex, France. Dostupno na: [http://www.tracfin.bercy.gouv.fr/pdf/rap2oIo_ang.pdf].
} 
Iako je, statistički gledano, broj prijava sumnjivih transakcija u porastu 22\% (u 2009. bio je 9,046, a u 20IO. II,O42), porast nije toliko značajan iz razloga što je skoro $20 \%$ prijavljenih transakcija u 2009. i 2010. obuhvaćalo intenzivnu djelatnost prebacivanja nezakonitih sredstava putem bankovnih računa trećim osobama te krađu osobnih podatka preko elektronske pošte ${ }^{35}$. Iz tog ugla gledano, ukupan broj prijava sumnjivih transakcija u razdoblju 2007- 20Io. nije se značajnije mijenjao, odnosno govori o jednoj konstanti primjene preventivne strategije u borbi protiv pranja novca i financiranja terorizma, $\mathrm{s}$ blagim porastom u 2010 .

Uzrok tako tog blagog porasta treba tražiti isključivo u legislativi. Članak II. njemačkog ${ }^{36}$ Zakona o otkrivanju sredstava proizašlih iz teških kaznenih djela propisuje tretman sumnjivih transakcija i nalaže obveznicima istog Zakona da, ukoliko imaju razloga vjerovati (bez obzira na iznos transakcije) da je počinjeno ili će biti počinjeno kazneno djelo prema članku 26I. njemačkog Kaznenog zakona (pranje novca) ili financiranje terorizma, neodgodivo obavijeste nadležna tijela usmeno. Kako bi se pojasnila "granica sumnje" prilikom detektiranja sumnjivih transakcija, njemački FIU je donio mišljenje kojim obveznici pritom moraju imati saznanje, sumnju ili osnovanu sumnju da će se pokušati ili sprovesti pranje novca ili financiranje terorizma. Nakon pojašnjenja navedenog članka II. njemačkog Zakona broj prijavljenih sumnjivih transakcija u 20Io. blago je porastao.

Uz sve dosad navedeno, posebno ističući relativno mali broj prijavljenih sumnjivih transakcija, ipak treba uzeti u obzir da je njemački FIU ustrojen kao policijski model što povlači određene reperkusije. Takvi FIU nisu prirodni sugovornik (ne)financijskih institucija zbog usredotočenja na mjere istrage na uštrb mjera prevencije. Iz tih se razloga ova vrsta FIU neprestano suočava s nepovjerenjem financijskih (osobito bankarskih) institucija, posebno kod klasificiranja transakcija koje nisu opisane zakonskim odredbama, a odišu nelogičnostima u poslovanju. Zapravo, takav FIU može biti neraspoložen za “aktivno sudjelovanje” koje zahtijevaju financijske institucije, a naročito u onim pravnim sustavima gdje je bankarska tajna tradicionalno utvrđena (Condemi i Pascal, 2005).

\section{I.2.2. SRBIJA, BUGARSKA I LIHTENŠTAJN}

Srbija se uskladila s međunarodnim standardima, prvenstveno s Trećom direktivom, tijekom 2009. Statistički podaci prijavljenih sumnjivih transakcija $(4,537)$ svakako idu u prilog njihovog povećanja, ali je zanimljivo primijetiti da daleko najvećim djelom prijave dolaze iz financijskog sektora, odnosno banaka. Uz to, iz Godišnjeg izvješća ${ }^{37}$ proizlazi da je u odnosu na 2009. zabilježen pad u ukupnom broju prijavljenih transakcija (što obuhvaća gotovinske i sumnjive transakcije).

Kako je u ovom radu stavljen naglasak na vrijednosti definicije sumnjivih transakcija koja se kroz statističke podatke očituje u primjeni, zanimljivo je usporediti zakonsku regulativu Republike Hrvatske

\footnotetext{
${ }^{35}$ Vidjeti više u Federal Criminal Police Office, FIU Germany Annual Report 20Io. Dostupno na: [http://www.bka.de/nn_I95I84/EN/Publications/AnnualReportsAndSituationAssessments/FinancialIntelligenceUnitFiuGermany/financialIntelligenceUnit FiuGermany_node.html?_nnn=true].

${ }^{36}$ Act on the Detection of Proceeds from Serious Crimes (August 2008). Dostupno na: [http://www.bka.de/nn_I94638/SharedDocs/Downloads/EN/Subjects_A_Z/FIU/moneyLaunderingAct2Oo8.html?_nnn=true].

37 Izvještaj o radu Uprave za sprečavanje pranja novca za 20Io. Dostupno na: [http://www.apml.org.rs/REPOSITORY/86_izvestaj-o-radu-uprave-za-sprecavanje-pranja-novca-za-2oIo.pdf].
} 
i Srbije, upravo zbog vrlo slične zakonske koncepcije uz znatnu razliku u definiranju sumnjivih transakcija. Uz sličnu povijest razvoja legislative sprječavanja pranja novca i usklađivanja $\mathrm{s}$ međunarodnim standardima, statistički podaci govore o dijametralno suprotnim rezultatima koje donosi praksa.

Uspoređujući zakonodavstvo Republike Hrvatske i Srbije te statističke podatke iz tabele I, može se doći do određenih zaključaka o primjeni sustava procjene rizika. Zakon o sprječavanju pranja novca i financiranja terorizma, osim što je u obje zemlje istog naziva, usporediv je čak i sadržajno, iako većinu pitanja koja nisu suštinske naravi Republika Hrvatska rješava podzakonskim aktima (pravilnicima). Tretiranje sumnjivih transakcija ipak se razlikuje. Dok hrvatski Zakon o sprječavanju pranja novca i financiranja terorizma sumnjivu transakciju opisuje vrlo detaljno, srpskim Zakonom nije definirana. U okviru obveza na dostavu podataka o transakcijama, članak 37. srpskog Zakona samo načelno propisuje spomenutu obvezu. Nadalje, usklađujući se s međunarodnim standardima i postupajući po odredbama ZSPNFT, Republika Hrvatska je već u idućoj godini (2009) pokazala drastične promjene u odnosu na poimanje i prijavljivanje sumnjivih transakcija. Srbija u promatranim godinama (2005-2010) bilježi stalni porast prijava sumnjivih transakcija zbog čega je razvidno da niti primjenom nove legislative nije odstupila od dotadašnjih principa djelovanja. Drugim riječima, normativno prihvaćanje sustava temeljenog na procjeni rizika nije rezultiralo istim ponašanjem u praksi.

Bugarska također svjedoči o porastu broja prijavljenih sumnjivih transakcija u razdoblju 2005-20IO. uz napomenu značajnog skoka u tom porastu u 20Io. Za razliku od 883 prijavljene sumnjive transakcije $u$ 2009, u 20IO. je prijavljeno I,460 sumnjivih transakcija (povećanje od 60\%) isključivo zbog velikog broj prijava voditelja registara vrijednosnih papira i novčarskih kuća. Analizirajući prijave sumnjivih transakcija u razdoblju 2005-2009. banke se ističu s prosječno 80\% prijava sumnjivih transakcija, dok u 20IO. sudjeluju samo s 50\%, u korist novčarskih kuća koje su u istoj godini dosegle udio u ukupnom broju prijavljenih sumnjivih transakcija s 35\%. Broj prijava ostalih institucija financijskog i nefinancijskog sektora još je uvijek ispodprosječan.

Posljednji u statističkoj analizi prijavljenih sumnjivih transakcija u razdoblju 2005--20Io. nalazi se Lihtenštajn. U tabeli I. se ističe kao negativni primjer provedbe sustava temeljenog na riziku što i ne čudi previše s obzirom da je 200o. smješten na "crnu listu” nekooperativnih zemalja. Stav pojedinih zemalja prema Lihtenštajnu nije od tada previše napredovao uzevši u obzir da ga je Slovenija, sukladno članku 22. i 38. slovenskog Zakona o sprječavanju pranja novca i financiranja terorizma, svrstala na popis zemalja kod kojih postoji mogućnost za pojavu pranja novca i financiranja terorizma. U prilog tome govori i podatak da je na 34,000 stanovnika i $160 \mathrm{~km}^{2}$ FIU Lihtenštajn u 20Io. zaprimio 26I sumnjivu transakciju (podatak je do I. IO. 20IO) $)^{38}$. Iz navedenog proizlazi da povećanje broja prijavljenih sumnjivih transakcija u Lihtenštajnu, bez obzira na legislativno usklađenje s međunarodnim standardima, nikako ne znači primjenu sustava temeljenog na procjeni rizika. U suprotnom, ova bi statistika išla u prilog tome da je Slovenija na dobrom tragu svrstavajući Lihtenštajn kao zemlju visokog

\footnotetext{
${ }^{8}$ Vidjeti više u izvješću MONEYVAL za Lihtenštajn. Dostupno na: [http://www.coe.int/t/dghl/monitoring/moneyval/Evaluations/Progress\%2oreports\%2O2y/MONEYVAL(2OIO)3O-ProgRep2LIE_en.pdf].
} 
rizika za pranje novca i financiranje terorizma. Na to ukazuje i podatak da broj dostavljenih predmeta nadležnim tijelima na daljnje postupanje $\mathrm{u}$ visokom postotku prati broj prijavljenih sumnjivih transakcija koji je ujedno jednak broju otvorenih predmeta od strane FIU Lihtenštajna.

\subsection{KRATKI PREGLED ANALIZIRANIH ZEMALJA U POGLEDU PRIMJENE SUSTAVA PROGJENE RIZIKA}

Kao što Završna studija inicijalno navodi, trend porasta prijava sumnjivih transakcija u nekim od promatranih zemalja doista ukazuje na učinkovitu provedbu sustava procjene rizika. Švicarska, Francuska i Njemačka svjedoče uspješnu kategorizaciju i procjenu rizika ne samo zbog povećanja ukupnog broja prijavljenih transakcija već i zbog sve veće participacije nebankarskog i nefinancijskog sektora $\mathrm{u}$ tom trendu rasta. Kako isključivo jedna kategorija, u ovom slučaju rast prijava sumnjivih transakcija, nije dostatan pokazatelj primjene sustava procjene rizika, ukazuje primjer Srbije i Bugarske gdje je statistička analiza ukazala na povećanje prijava sumnjivih transakcija isključivo u bankarskom sektoru.

Upravo suprotno, broj prijavljenih sumnjivih transakcija u Republici Hrvatskoj koji je u evidentnom padu također svjedoči učinkovitoj primjeni sustava procjene rizika. Razlozi takvog zaključka proizlaze iz legislativne podloge koja vrlo detaljno opisuje sumnjivu transakciju s jedne strane i aktivnog uključenja obveznika (prilikom izrade indikatora, edukcijom i konačno kaznenim odredbama) u sustav prevencije pranja novca i financiranja terorizma s druge strane. Na taj su način prijave sumnjivih transakcija dobile na težini i kvaliteti što je posljedično vidljivo na omjeru prijavljenih transakcija i otvorenih predmeta od strane Ureda, iako još uvijek ima prostora za daljnji napredak.

Analizirajući podatke o prijavljenim sumnjivim transakcijama Nizozemske i Slovenije nameće se nekoliko mogućih zaključaka. Slovenski sustav procjene rizika, usprkos svim nezakonitostima prilikom prijava sumnjivih transakcija (varijabilnost broja prijava u promatranom razdoblju), ipak ukazuje na primjenu sustava procjene rizika zbog niskog broja prijavljenih sumnjivih transakcija koje bez iznimaka čine ukupan broj otvorenih predmeta u slovenskom FIU. Nizozemska pak strogo odvaja novčane od nenovčanih transakcija prilikom čega se $\mathrm{u}$ velikom postotku ističe porast broja sumnjivih $\mathrm{i}$ to nenovčanih transakcija prijavljenih od strane banaka, dok broj prijava sumnjivih nenovčanih transakcija nefinancijskog sektora pada. Iako ti podaci u osnovi ne idu u prilog provedbi sustava temeljenog na procjeni rizika, opravdanje za navedenu situaciju ipak se može pronaći u promjeni trendova pranja novca.

Prilikom analize podataka o prijavljenim sumnjivim transakcijama za Ukrajinu i Lihtenštajn, bez obzira što je kod Ukrajine zabilježen pad prijava transakcija, a kod Lihtenštajna rast, zaključak se sam po sebi nameće. Sveukupno preveliki broj prijava govori o manjkavostima u više segmenata, od legislativnih temelja do provedbe u praksi, što još jednom potvrđuje da broj prijavljenih sumnjivih transakcija nije dovoljno indikativan kriterij ocjene učinkovitosti primjene sustava procjene rizika. 
Zaključno, potvrdu učinkovite primjene sustava procjene rizika zacijelo treba tražiti u više segmenata, razmatrajući svaki sustav prevencije pranja novca i financiranja terorizma zasebno, od razvoja legislative do konkretnih pomaka koje poduzima pojedina država u praksi.

\section{ZAKLJUČAK}

Uzimajući u obzir sva nastojanja prilikom definiranja učinkovitog sustava prevencije pranja novca koji se temelji na procjeni rizika, sveobuhvatna statistika koja je prvenstveno ogledalo prakse govori $\mathrm{u}$ prilog nekoliko zaključaka:

a) učinkoviti sustav procjene rizika zahtjeva primjerenu legislativnu podlogu s razrađenom definicijom sumnjivih transakcija, učinkoviti nadzor i primjerene sankcije u slučaju nepoštovanja zakonskih odredaba,

b) sustav procjene rizika zahtjeva sve veći udio sumnjivih transakcija prijavljenih od nefinancijskih institucija kao potvrdu podizanja stupnja svijesti i u tom sektoru,

c) permanentnoj izobrazbi svih institucija uključenih u provođenje mjera prevencije pranja novca i financiranja terorizma na nacionalnoj razini.

Navedene zaključke podupire i prethodna statistička analiza deset zemalja po kriteriju uočenog porasta ili pada broja prijavljenih sumnjivih transakcija. Oživotvorenje sustava procjene rizika ne može se mjeriti prema kriteriju porasta prijave sumnjivih transakcija. Za pojedine zemlje kao što su Švicarska, Francuska, Njemačka i Nizozemska takvo povećanje svjedoči aktivnoj primjeni sustava procjene rizika, dok isto povećanje broja prijavljenih sumnjivih transakcija u Srbiji, Bugarskoj i Lihtenštajnu govori sasvim suprotno. Pritom, niti razlike u organizaciji FIU nisu imale većeg utjecaja.

Jednako tako, smanjenje broja prijavljenih sumnjivih transakcija u Republici Hrvatskoj, Sloveniji i Rumunjskoj ne znači manjkavu primjenu sustava procjene rizika. Upravo suprotno, usklađivanjem domaćeg zakonodavstva s međunarodnim standardima sprječavanja pranja novca i financiranja terorizma ove su zemlje dokazale svoju spremnost na promjenu kroz manji broj prijava sumnjivih transakcija sadržajno visoke kvalitete.

Iz provedene analize jasno proizlazi da sposobnost donošenja utemeljene odluke o ponašanju stranke ili o provedenoj transakciji možemo promatrati isključivo kao posljedicu sveobuhvatne legislative, permanentne izobrazbe i up-to-date shvaćanja rizika te konačno, učenja na vlastitim greškama.

Temeljem navedenog može se zaključiti da razvoj svakog sustava pa tako i sustava temeljenog na procjeni rizika zahtjeva široki spektar izvora informacija, sveobuhvatnu obradu i dugogodišnju praksu, $\mathrm{u}$ cilju što kvalitetnije interpretacije prikupljenih informacija te njihove kategorizacije. Njegova primjena predstavlja osnove za daljnji razvoj politika i procedura djelovanja, usavršavajući sustav pred kojim se svakodnevno pojavljuju novi izazovi. 


\section{REFERENGE}

I. Act on the Detection of Proceeds from Serious Crimes, August 2008 (Germany). Dostupno na: 〈http://www.bka.de/nn_I94638/SharedDocs/Downloads/EN/Subjects_A_Z/FIU/moneyLau nderingAct20o8.html?_nnn=true>.

2. Cindori, S., 2008. Organizacija financijsko-obavještajnih jedinica za sprječavanje pranja novca. Hrvatska javna uprava, 8(I), pp. I7I-203.

3. Cindori, S., 20IO. Sustav sprječavanja pranja novca. Zagreb, Faculty of Law.

4. Condemi, M. and De Pascal, F., 2005. International profiles of the activity to prevent and combat money laundering. Roma: Ufficio italiano dei cambi.

5. Council Directive 9I/308/EEC of Io June I99I on prevention of the use of the financial system for the purpose of money laundering.

6. Directive 200I/97/EC of the European Parliament and of the Council of 4 December 200I amending Council Directive 9I/308/EEC on prevention of the use of the financial system for the purpose of money laundering.

7. Directive 2005/60/EC of the European Parliament and of the Council of 26 October 2005 on the prevention of the use of the financial system for the purpose of money laundering and terrorist financing.

8. FATF, 2007. Guidance on the Risk-Based Approach to combating money laundering and terrorist financing. Paris: Financial Action Task Force.

9. FATF, 2OI2. Methodology for Assessing Compliance with the FATF 40 Recommendations and the FATF 9 Special recommendations. Paris: Financial Action Task Force.

Io. Federal Criminal Police Office, 20Iо. Annual Report 20Io. [online] Dostupno na: <http://www.bka.de/nn_I95I84/EN/Publications/AnnualReportsAndSituationAssessments/Fin ancialIntelligenceUnitFiuGermany/financialIntelligenceUnitFiuGermany_node.html?_nnn=tru e>.

II. Federal Office of Police, 20Iо. Annual report 20Io. [online] Dostupno na: 〈http://www.fedpol.admin.ch/content/fedpol/en/home/dokumentation/berichte/geldwaesch erei.html $>$.

I2. Final Study on the Application of the Anti-Money Laundering Directive, Service Contract ETD/2009/IM/F2/90, 2009, Brussels, European Commission DG Internal Market and Services Budget.

13. Government Decision no. 594/2008 on the approval of the Regulation for application of the provisions of the Law no. 656/2002 for the prevention and sanctioning money laundering as well as for instituting of some measures for prevention and combating terrorism financing acts (Romania).

I4. Graham, T., Bell, E. i Elliott, N., 2006. Money Laundering. Wiltshire: Butterworth-Heinemann.

I5. Heršak, G., 1993. Pranje novca i policija. Policija i sigurnost, I(I-2), pp. 3-4.

I6. Law no. 656 of December 7 th, 2002 on the prevention and sanctioning of money laundering and on setting up of certain measures for the prevention and combating terrorism financing, consequently amended and completed (Romania).

17. Law of Ukraine on Prevention and Counteraction to Legalization (Laundering) of the Proceeds from Crime or Terrorist Financing as of 18.05.20IO, no 2258. Dostupno na: < http://www.coe.int/t/dghl/monitoring/moneyval/Evaluations/progress\%2oreports/MONEYVAL(2OIO)I_Pr ogRep_UKR_en.pdf $>$.

I8. Main elements related to National Office for Prevention and Control of Money Laundering's activity, performed within the year 20I0, Synthesis of the activity report. Bucharest.

19. Ministastvo za finance Republike Slovenije. Poročilo o delu Urada Republike Slovenije za preprečevanje pranja denarja za leto 20Io. Dostupno na: <http://www.uppd.gov.si/si/delovna_podrocja/podatki_o_delu_urada/>.

20. Ministry of Finance of RC. Annual Reports of Ministry of Finance, 2009-20Io. [online] Dostupno na: 〈http://www.mfin.hr/en/annual-reports-of-ministry-of-finance〉.

21. Mitsilegas, V., 2003. Money Laundering Counter-Measures in the European Union: A New Paradigm of Security Governance Versus Fundamental Legal Principles. The Hague: Kluwer Law International.

22. MONEYVAL, 20Io. Izveštaj o radu Uprave za sprečavanje pranja novca za 20Io. Dostupno na: <http://www.coe.int/t/dghl/monitoring/moneyval/Evaluations/progress\%2oreports/MONEY VAL(2OIO)33ProgRep-SRB_en.pdf $>$.

23. MONEYVAL, 20II. Croatia: Progress report and written analysis by the Secretariat of Core Recommendations. Dostupno na: 〈http://goo.gl/WZRq7〉. 
24. Pravilnik o obavješćivanju Ureda za sprječavanje pranja novca o sumnjivim transakcijama i osobama, NN I/og. Zagreb: Narodne novine.

25. Richards, J., 1998. Transnational Criminal Organizations, Cybercrime, and Money Laundering: A Handbook for Law Enforcement Officers, Auditors and Financial Investigators. Florida: CRC Press LLC. doi: IO.I2OI/978I420048728

26. Savona, E., 2004. Responding to Money Laundering: International Perspectives. London: Harwood Academic Publishers.

27. The Federal Act on Combating Money Laundering in the Financial Sector (Anti-Money Laundering Act) of Io October 1997 (Switzerland).

28. TRAFCIN, 20IO. Rapport dactivité 20IO. Montreuil-sous-Bois cedex, France. Dostupno na: 〈http://www.sacem.fr/cms/home/la-sacem/rapports-activite〉.

29. Uredba o unutarnjem ustrojstvu Ministarstva financija, NN 29/og. Zagreb: Narodne novine.

30. Zakon o preprečevanju pranja denarja in financiranja terorizma, Ur. 1. RS 6o/O7, 47/o9, 48/o9, I9/IO, 77/II. Ljubljana: Uradni list.

3I. Zakon o sprečavanju pranja novca i finansiranja terorizma, Službeni glasnik RS, 20/o9, 72/o9 i 9I/IO).

32. Zakon o sprječavanju pranja novca i financiranja terorizma, NN 87/o8. Zagreb: Narodne novine.

33. Zakon o sprječavanju pranja novca, NN 69/97, IO6/97, 67/OI, II4/OI, II7/O3 i I42/o3. Zagreb: Narodne novine. 